\title{
EFEKTIVITAS PROMOSI KESEHATAN BERBASIS AUDIOVISUAL DALAM MENINGKATKAN KEPATUHAN MINUM OBAT FILARIASIS DI KABUPATEN KUNINGAN
}

\author{
Nissa Noor Annashr, Icca Stella Amalia \\ Program Studi Kesehatan Masyarakat STIKes Kuningan \\ annashr.nissa46@gmail.com
}

\begin{abstract}
Abstrak
Kuningan merupakan kabupaten endemis filariasis di Jawa Barat. Pada tahun 2016 terdapat 48 kasus dan 1 orang penderita meninggal dunia. Tujuan dari penelitian ini adalah menganalisis pengaruh promosi kesehatan berbasis audiovisual dalam meningkatkan kepatuhan minum obat filariasis di Kabupaten Kuningan. Penelitian ini merupakan Experimental Quasi dengan rancangan Nonequivalent Comparison Group Design. Sampel diambil dengan teknik purposive sampling dan terbagi ke dalam 2 kelompok yaitu kelompok pembanding dan kelompok eksperimen, masing-masing berjumlah 53 orang. Kelompok pembanding bearasal dari Desa Linggajati, Kecamatan Cilimus diberikan promosi kesehatan metode ceramah dan kelompok eksperimen berasal dari Desa Bandorasawetan, Kecamatan Cilimus diberikan promosi kesehatan metode ceramah ditambah media audiovisual. Instrumen yang digunakan dalam penelitian adalah kuesioner. Data dianalisis secara univariat dan bivariat menggunakan uji chi square. Hasil penelitian menunjukkan pada kelompok eksperimen, terdapat perbedaan signifikan proporsi responden yang minum obat pencegahan filaraisis antara sebelum dan setelah diberikan promosi kesehatan metode ceramah dan penayangan video, nilai $\mathrm{p}$ sebesar 0,008 . Pada kelompok pembanding, terdapat perbedaan signifikan proporsi responden yang minum obat pencegahan filariasis antara sebelum dan setelah diberikan promosi kesehatan metode ceramah dan penayangan video, nilai p sebesar 0,075. Kesimpulan penelitian, promosi kesehatan dengan menambahkan media audiovisual lebih efektif dibanding hanya menggunakan metode ceramah, dalam meningkatkan kepatuhan masyarakat untuk minum obat pencegahan filariasis.
\end{abstract}

Kata kunci : promosi kesehatan, audiovisual, kepatuhan, obat filariasis

\section{Pendahuluan}

Filaraisis limfatik merupakan
penyakit yang disebabkan cacing mikroskopik, dimana cacing dewasa hidup di sistem limfe manusia dan menyebabkan penyakit (Goel, 2016). Terlepas dari kemajuan di bidang pengendalian vektor dan kemoterapi, penyakit yang disebabkan karena cacing parasit filaria ini masih menjadi penyebab signifikan dari morbiditas di berbagai belahan dunia. Sekitar 751 juta individu tinggal di daerah endemis filariasis. Diperkirakan 91\% kasus filariasis disebabkan oleh cacing Wuchereria bancrofti dan hanya 9\% disebabkan oleh Brugia timori dan Brugia malayi (Nutman, 2000).

Pada tahun 2009, jumlah kabupaten/kota yang endemis filariasis meningkat menjadi 356 kabupaten/kota (71,9\%), sedangkan 139 kabupaten/kota $(28,1 \%)$ tidak endemis filariasis. Jumlah kasus kronis filariasis yang dilaporkan sampai tahun 2009 sebanyak 11.914 kasus (Kemenkes RI, 2010). Sementara itu, pada 
tahun 2010 terdapat 11.969 kasus dan pada tahun 2014 meningkat menjadi 14.932 kasus filariasis (Kemenkes RI, 2015).

Berdasarkan Peraturan Menteri Kesehatan Republik Indonesia Nomor 94 Tahun 2014 tentang Penanggulangan Filariasis, Indonesia telah sepakat untuk melaksanakan eliminasi Filariasis tahun 2020 sesuai ketetapan WHO tentang Kesepakatan Global Eliminasi Filariasis tahun 2020 (The Global Goal of Elimination of Lymphatic Filariasis as a Public Health Problem by the Year 2020. Salah satu program eliminasi filariasis yaitu Pemberian Obat Pencegahan Secara Massal Filariasis yang selanjutnya disebut POPM Filariasis adalah pemberian obat yang dilakukan untuk mematikan mikrofilaria secara serentak kepada semua penduduk sasaran di wilayah endemis Filariasis.

Hasil penelitian Alamsyah menunjukan bahwa cakupan minum obat filariasis di wilayah kerja Puskesmas Bangko, Riau sebesar 34,4 \%. Variabel yang memiliki hubungan bermakna dengan minum obat pencegahan filariasis, yaitu tingkat pengetahuan, jenis kelamin, pekerjaan, rasa takut terhadap efek samping obat filariasis, serta sosialisasi petugas kesehatan (Alamsyah, 2016).

Kabupaten Kuningan sebagai daerah endemis filariasis, menyelenggarakan program POMP sejak tahun 2015. Laporan kasus filariasis dari Dinas Kesehatan Kabupaten Kuningan menunjukkan jumlah kasus filaraisis di Kabupaten Kuningan tahun 2006 sebanyak 48 kasus yang tersebar pada 15 kecamatan.

Kecamatan Cilimus menjadi kecamatan yang menempati peringkat ke-2 jumlah kasus filariasis terbanyak di Kabupaten Kuningan yaitu sebanyak 4 kasus pada tahun 2017. Cakupan minum obat pencegahan filaraisis dari jumlah penduduk di 2 wilayah kerja puskesmas yang terdapat di Kecamatan Cilimus masih di bawah target pemerintah $(86 \%)$ yaitu 75,14\% di Puskesmas Cilimus) dan 70,72\% di Puskesmas Linggarjati.
Berdasarkan hal tersebut maka peneliti tertarik untuk melakukan penelitian mengenai efektivitas promosi kesehatan berbasis audiovisual dalam meningkatkan kepatuhan minum obat pencegahan filaraisis di Kabupaten Kuningan. Tujuan penelitian adalah menganalisis efektivitas promosi kesehatan berbasis audiovisual dalam meningkatkan kepatuhan minum obat filariasis di Kabupaten Kuningan.

\section{Metode Penelitian}

Penelitian ini dilakukan pada Bulan Mei hingga Oktober tahun 2018 di Kecamatan Cilimus, Kabupaten Kuningan. Jenis penelitian ini yaitu penelitian eksperimen yang bertujuan untuk mengetahui efektivitas promosi kesehatan berbasis audiovisual dalam meningkatkan kepatuhan minum obat pencegahan filariasis dalam program pemberian obat massal pencegahan (POMP) filariasis. Rancangan penelitian yang digunakan yaitu Experimental Quasi atau eksperimen semu dengan Nonequivalent Comparison Group Design sehingga terdapat satu kelompok eksperimen (intervensi) dan satu kelompok pembanding. Populasi penelitian adalah seluruh ibu dari tiap rumah tangga (perhitungan sama dengan jumlah Kepala Keluarga/KK) di Kecamatan Cilimus, Kabupaten Kuningan. Teknik pengambilan sampel menggunakan Non Probability Sampling dengan Purpossive Sampling.

Berdasarkan perhitungan besar sampel minimal, diketahui besar sampel minimal untuk masing-masing kelompok sebanyak 53 orang. Kelompok eksperimen atau intervensi terdiri dari 53 orang ibu yang mewakili tiap rumah tangga di Desa Bandorasawetan, Kecamatan Cilimus dan kelompok pembanding terdiri dari 53 orang ibu berasal dari Desa Linggajati, Kecamatan Cilimus.

Terdapat dua jenis variabel dalam penelitian ini, yaitu variabel independen 
berupa dan variabel dependen. Variabel independen berupa metode pemberian promosi kesehatan, terdiri dari 2 kategori yaitu kategori pertama adalah metode ceramah dan kategori kedua adalah metode ceramah ditambah dengan media audiovisual menggunakan video, sedangkan variabel dependen adalah kepatuhan minum obat pencegahan filaraisis pada program pemberian obat massal pencegahan (POMP) filariasis. Kedua variabel tersebut diukur dengan menggunakan instrumen berupa kuesioner yang diisi oleh responden sebelum dan setelah diberikan perlakuan tau intervensi berupa promosi kesehatan dengan metode berbeda pada masingmasing kelompok.

Analisis data dilakukan dengan analisis univariat dan bivariat. Uji statistik yang digunakan dalam analisis bivariat adalah uji chi square untuk menganalisis perbedaan proporsi kepatuhan minum obat pencegahan filariasis antara sebelum dan setelah diberikan promosi kesehatan pada masing-masing kelompok.

\section{Hasil Penelitian}

Tabel 1. Kepatuhan Minum Obat Pencegahan Filariasis Sebelum dan Setelah diberikan Promosi Kesehatan dengan Metode Ceramah dan Media Audiovisual

\begin{tabular}{llcccc}
\hline \multicolumn{2}{c}{ Variabel Perilaku } & Frekuesi & Persentase & $\begin{array}{c}\text { Persentase } \\
\text { Kenaikan } \\
\text { Minum Obat }\end{array}$ & nilai p \\
\hline $\begin{array}{llcll}\text { Sebelum diberikan } \\
\text { promkes }\end{array}$ & $\begin{array}{l}\text { Minum Obat } \\
\text { Tidak minum } \\
\text { obat }\end{array}$ & 36 & 67,9 & & \\
\cline { 1 - 2 } $\begin{array}{l}\text { Setelah diberikan } \\
\text { promkes }\end{array}$ & $\begin{array}{l}\text { Minum obat } \\
\text { Tidak minum } \\
\text { obat }\end{array}$ & 49 & 32,1 & 36,1 & 0,008 \\
\hline
\end{tabular}

Berdasarkan tabel 1, dapat diketahui bahwa ada kenaikan jumlah responden yang minum obat pencegahan filariasis antara sebelum dan setelah diberikan promosi kesehatan menggunakan media audiovisual yaitu persentasenya sebesar 36,1\%. Hasil analisis bivariat didapatkan nilai $\mathrm{p}$ sebesar $0,008 \quad(\mathrm{p} \leq 0,05)$. Hal tersebut menunjukkan bahwa terdapat perbedaan yang signifikan proporsi kepatuhan minum obat pada responden antara sebelum dan setelah diberikan promosi kesehatan dengan metode audiovisual.

\section{Tabel 2. Kepatuhan Minum Obat Pencegahan Filariasis Sebelum dan Setelah diberikan Promosi Kesehatan dengan Metode Ceramah}

\begin{tabular}{|c|c|c|c|c|c|}
\hline \multicolumn{2}{|c|}{ Variabel Perilaku } & \multirow{2}{*}{$\begin{array}{c}\text { Frekuesi } \\
49\end{array}$} & \multirow{2}{*}{$\begin{array}{c}\text { Persentase } \\
92,5\end{array}$} & \multirow{2}{*}{$\begin{array}{c}\text { Persentase } \\
\text { Kenaikan } \\
\text { Minum Obat }\end{array}$} & \multirow[t]{2}{*}{ nilai $\mathbf{p}$} \\
\hline Sebelum diberikan & Minum Obat & & & & \\
\hline promkes & Tidak minum obat & 4 & 7,5 & \multirow{3}{*}{8,2} & \multirow{3}{*}{0,075} \\
\hline Setelah diberikan & Minum obat & 53 & 98,1 & & \\
\hline promkes & Tidak minum obat & 1 & 1,9 & & \\
\hline
\end{tabular}


Berdasarkan tabel 2, dapat diketahui bahwa ada kenaikan jumlah responden yang minum obat pencegahan filariasis antara sebelum dan setelah diberikan promosi kesehatan menggunakan media audiovisual yaitu persentasenya sebesar 8,2\%. Hasil analisis bivariat didapatkan nilai $\mathrm{p}$ sebesar $0,075 \mathrm{p}$

\section{Pembahasan}

\section{Hasil penelitian menunjukkan} bahwa pada kelompok pembanding, terdapat kenaikan proporsi responden yang minum obat setelah diberikan promosi kesehatan dengan metode ceramah dimana persentase kenaikannya sebesar $8,2 \%$. Hal tersebut sejalan dengan penelitian Ramadhani (2009) yang menunjukkan PSP (pengetahuan, sikap, perilaku) pencegahan filariasis relatif baik setelah diberikan intervensi berupa edukasi kesehatan. Edukasi kesehatan dengan metode ceramah menunjukkan dapat meningkatkan PSP pencegahan filariasis. Cakupan minum obat pencegahan filariasis pada kelompok intervensi lebih tinggi $(9,9 \%)$ dibandingkan kelompok kontrol $(4 \%)$.

Penelitian Santoso, dkk (2014) membuktikan promosi kesehatan dapat meningkatkan PSP masyarakat dalam pengobatan filariais $(\mathrm{p}<0,05)$. Perilaku minum obat mengalami peningkatan setelah diberikan promosi kesehatan dari 70,1\% menjadi 88,9\% (Santoso, 2014).

Pada kelompok intervensi atau eksperimen dalam penelitian ini, persentase kenaikan cakupan minum obat filariasis sebelum dan setelah mendapatkan promosi kesehatan dengan metode ceramah maupun ditambah media audiovisual sebesar 36,1\%. Persentase tersebut jauh lenih tinggi dibandingkan dengan persentase pada kelompok $\leq 0,05)$. Hal tersebut menunjukkan bahwa terdapat perbedaan yang signifikan proporsi kepatuhan minum obat pada responden antara sebelum dan setelah diberikan promosi kesehatan dengan metode ceramah.

pembanding. Data ini menunjukkan bahwa penggunaan audiovisual dapat membantu mengubah perilaku lebih baik daripada hanya dengan metode ceramah. Hasil penelitian ini sejalan dengan hasil penelitian Papilaya, dkk (2016) yang menunjukkan bahwa media audiovisual memiliki kemampuan lebih baik dalam memperbaiki perilaku pemeliharaan kesehatan gigi dan mulut (kategori baik menjadi $71 \%$ ). Begitu juga dengan penelitian Claudia (2017) dimana metode penyuluhan melalui media audio, visual dan audiovisual memiliki pengaruh terhadap oral hygiene penderita Schizophrenia di RSJ Daerah Surakarta dengan nilai $\mathrm{p}$ sebesar 0.001. Penelitian oleh Hendri, dkk (2018) menunjukkan bahwa pelatihan kader menggunakan media audiovisual dan media cetak dapat meningkatkan perilaku kader dalam mendukung program pemberian obat massal pencegahan filaraisis, dimana persentase perilaku dengan kategori baik semula $41,9 \%$ kemudian berubah menjadi 90,3\% setelah diberikan pelatihan (Hendri, 2018).

Ada beberapa faktor yang dapat mempengaruhi perilaku seseorang untuk minum obat pencegahan filariasis, sebagaimana disebutkan dalam penelitian Marathe di India, 2 alasan utamanya adalah rasa takut terhadap efek samping dan tidak menerima obat filariasis. Upaya KIE (komunikasi, informasi dan edukasi) mengenai filariasis dengan perangkat audiovisual hanya menjangkau 31,67\% rumah tangga di Kabupaten Chhatarpur, Madhya Pradesh, India (Marathe, 2015). 
Dengan demikian, disimpulkan bahwa pengetahuan yang memadai tentang efek samping obat dan manfaat dapat mempengaruhi perilaku masyarakat untuk minum obat filariasis.

Penyuluhan sebagai salah satu bentuk promosi kesehatan memiliki pengaruh signifikan terhadap perubahan perilaku minum obat filariasis. Perubahan perilaku menurut teori stimulus organisme terjadi karena dengan adanya stimulus yang diberikan terhadap organisme maka organisme bereaksi sehingga terjadi perubahan perilaku (Maulana 2009). Salah satu strategi untuk memperoleh perubahan perilaku menurut WHO yang dikutip oleh Notoatmodjo (2010) adalah dengan pemberian informasi untuk meningkatkan pengetahuan sehingga menimbulkan kesadaran dan dapat dilakukan dengan pemberian penyuluhan kesehatan. Adanya perubahan perilaku dalam penelitian ini dipengaruhi oleh adanya peningkatan pengetahuan dan sikap pada responden. Hal ini sesuai dengan teori Green bahwa perubahan perilaku dapat dipengaruhi oleh beberapa faktor salah satunya faktor predisposisi dalam hal ini pengetahuan dan sikap (Notoatmodjo 2014).

Dengan adanya penyuluhan menggunakan media audiovisual membuat penerima penyuluhan menggunakan lebih banyak indera dibandingkan dengan penyuluhan yang hanya menggunakan media audio. Media audiovisual mendorong penerimanya untuk menggunakan indera pendengar dan indera pengelihatan agar informasi dapat diterima dengan baik.

Menurut Edgar Dale (1946) dalam Notoatmodjo (2007), semakin banyak indera yang digunakan manusia untuk menerima sesuatu maka semakin jelas pula pengetahuan atau informasi yang diperoleh. Daya penyerapan informasi atau pengetahuan seseorang dapat dipengaruhi oleh alat bantu atau media yang digunakan dalam proses pendidikan. Seseorang dalam proses pendidikan dapat memperoleh pengalaman/pengetahuan melalui berbagai macam alat bantu, tetapi masing-masing alat bantu memiliki intensitas yang berbeda dalam membantu menangkap pengetahuan. Alat bantu berupa media audiovisual memiliki intensitas penyerapan lebih tinggi yaitu sebesar $30 \%$, dibandingkan intensitas alat bantu berupa visual hanya $20 \%$ atau verbal hanya $10 \%$ (Notoatmodjo, 2007).

\section{Kesimpulan dan Saran}

\section{Kesimpulan}

Promosi kesehatan terbukti efektif dapat meningkatkan kepatuhan masyarakat dalam minum obat pencegahan filariasis. Promosi kesehatan menggunakan media audiovisual memiliki efektivitas lebih tinggi dalam meningkatkan kepatuhan masyarakat untuk minum obat pencegahan filariasis.

\section{Saran}

Berdasarkan hasil penelitian, untuk dapat meningkatkan cakupan minum obat pencegahan filaraisis, maka diharapkan pemerintah dapat meningkatkan upaya promotif dengan menggunakan media yang menarik seperti media audiovisual sehingga intensitas penyerapan informasi atau pengetahuan masyarakat terhadap materi dari promosi kesehatan dapat meningkat.

\section{Ucapan Terimakasih}

Kementerian Riset dan Pendidikan Tinggi, Ketua Yayasan Pendidikan Bhakti Husada Kuningan, Ketua STIKes Kuningan, Ketua Lembaga Penelitian STIKes Kuningan, IAKMI Kab. Kuningan, Dinas Kesehatan Kab. Kuningan, Puskesmas Linggajati dan Puskesmas Cilimus, masyarakat Desa Linggajati dan Bandorasawetan. 


\section{Referensi}

Alamsyah, Agus dan Marlina, Tuti. 2016. Faktor-Faktor yang Berhubungan dengan Cakupan Menelan Obat Massal Pencegah Filariasis. Journal Endurance, 1 (1) : 17-2

Claudia, Ave . Karya, Edi dan Gunawan. 2017. Pengaruh Metode Penyuluhan Melalui Media Audio, Visual Dan Audiovisual Terhadap Oral Hygiene Penderita Schizophrenia Kategori Tenang Di Rsj Daerah Surakarta. Jurnal lmu Kedokteran Gigi, 1 (1)

Dinas Kesehatan Kabupaten Kuningan. 2016. Data Penderita Kasus Kronis Filariasis Di Kabupaten Kuningan

Dinas Kesehatan Kabupaten Kuningan. 2017. Laporan Cakupan Hasil Pelaksanaan POMP Filariasis

Goel, Trilok Chandra dan Goel, Apul. 2016. Lymphatic Filariasis. Singapore : Springer Science + Business Media Singapore

Hendri, Joni., Ipa, Mara., Ginanjar, Aryo., Yuliasih, Yuneu., dan Astuti, Endang Puji. 2018. Intervensi Kader dalam Mendukung Program Pemberian Obat Massal Pencegahan (POMP) Filariasis di Kecamatan Cibeureum dan Cibingbin, Kabupaten Kuningan, Provinsi Jawa Barat. Jurnal Ekologi Kesehatan, 17 (1) : 31 - 40

Kemenkes RI. 2014. Mengenal Filariasis (Penyakit Kaki Gajah). Jakarta : Direktorat Jenderal PP dan PL.

Kementerian Kesehatan RI. 2010. Filariasis di Indonesia. Buletin Jendela Epidemiologi Volume 12010

Kementerian Kesehatan RI. 2015. Profil Kesehatan Indonesia 2014. Jakarta. http://www.depkes.go.id

Marathe, Neera, and Chalisgaonkar, Charudatt. 2015. Mass Drug Administration Coverage Evaluation for Elimination of Lymphatic Fiariasis in Chhatarpur District of Madhya Pradesh. International Journal of Medical Science and Public Health, 4 (7)

Maulana, H. 2009. Promosi Kesehatan. Jakarta : Penerbit Buku Kedokteran EGC

Notoatmodjo, S. 2014. Ilmu Perilaku Kesehatan. Jakarta : Rineka Cipta.

Notoatmodjo, Soekidjo. 2007. Promosi Kesehatan dan Ilmu Perilaku. Jakarta : Penerbit Rineka Cipta

Notoatmodjo, Soekidjo. 2010. Promosi Kesehatan dan Perilaku Kesehatan. Jakarta : Rineka Cipta.

Nutman, Thomas B., series editor G. Pasvol, G. dan Hoffman, S. I.. 2000. Lymphatic Filariasis. London : Imperial College Press.

Papilaya, Zuliari, Juliatri. 2016. Perbandingan Pengaruh Promosi Kesehatan menggunakan Media Audio dengan Media Audio-visual terhadap Perilaku Kesehatan Gigi dan Mulut Siswa SD. Jurnal e-GiGi (eG), 4 (2)

Ramadhani, Tri dan Sudomo, M. 2009. Peningkatan Peran Serta Masyararat dalam Pengobatan Filariasis Limfatik di Kecamatan Tirto Kabupaten Pekalongan. Media Penelitan dan Pengembangan Kesehatan, 19 (3)

Santoso; Taviv, Yulian, Yahya; Mayasari, Rika. 2014. Pengaruh Promosi Kesehatan terhadap Pengetahuan, Sikap dan Perilaku Masyarakat tentang Filariasis. Buletin Penelitian Sistem Kesehatan, 17 (2) : 167-176 